\title{
Scrapie and bovine spongiform encephalopathy: immunological properties and diagnosis for food products
}

\author{
A Paraf \\ Laboratoire de pathologie infectieuse et immunologie, Inra, 37380 Nouzilly, France
}

(Received 12 June 1996; accepted 29 August 1996)

\begin{abstract}
Summary - While spongiform encephalopathies do not cross, in principle, the species barrier in natural conditions, experimental transmission has been shown to be dependent of the host gene expressing the prion protein $\left(\mathrm{PrP}^{\mathrm{C}}\right)$. Cerebral and peritoneal routes are the most successful for experimental transmission, ie, from sheep to cow, but the oral route is the most probable for the natural transmission. In natural conditions there is no immune response in the infected but tolerant animal, whatever the species. It is possible to obtain specific polyclonal and monoclonal antibodies, which, however, do not distinguish $\mathrm{PrP}^{\mathrm{C}}$ from the disease-specific prion protein (PrPsC). Transmission of scrapie (SC) or bovine spongiform encephalopathy (BSE) to humans, either by meat or by milk, has not been demonstrated.
\end{abstract}

prion / antibody / scrapie / BSE

Résumé - Scrapie et encéphalopathie spongiforme bovine : propriétés immunologiques et diagnostic pour les aliments. Bien que dans les conditions naturelles, les infections à prions ne franchissent pas la barrière d'espèce, mis à part quelques exemples du mouton à la chèvre ou du bovin au chat, on a démontré expérimentalement que la transmission interespèce est possible, dépendante du gène exprimant le prion $\left(P P^{C}\right)$. Expérimentalement, les voies cérébrale et péritonéale sont les plus efficaces (par exemple pour la transmission de la tremblante du mouton aux bovins) mais la voie orale est la plus probable dans le cas de transmission naturelle. Dans les conditions naturelles, il n'y a pas de réponse immune chez l'animal infecté, qui se trouve en état de tolérance, quelle que soit l'espèce animale étudiée. Il est possible d'obtenir des anticorps polyclonaux et monoclonaux, qui cependant ne permettent pas de distinguer le prion normal (PrPC) du prion pathogène $\left(P r P^{S C}\right)$. II n'existe pas de transmission à l'homme, soit de scrapie ovine (SC), soit d'encéphalopathie spongiforme bovine (BSE) par consommation de viande ou de lait, qui ait été démontrée.

prion / anticorps / tremblante / ESB 


\section{INTRODUCTION}

Recently, a wave of panic disseminated all over Europe with the idea that bovine spongiform encephalopathy (BSE) could be transmitted to humans in the form of Creutzfeldt-Jakob disease (CJD). Because of the spread of BSE in England since 1986 and an apparent upsurge of CJD in Europe, it was claimed by certain media and politicians that cows from England could be at the origin of the development of the disease in humans. Due to the lack of knowledge of scientists, no scientific answer could be given to the question: are BSE and/or sheep scrapie transmissible to humans? In fact, many important questions have remained unanswered: how is it possible to obtain specific antibodies against the pathogenic form of prions to design a diagnosis test? How is it possible to pass a prion disease from infected to healthy animals of different species? Is the infectious agent a pure protein or a viroid? Is the pathogenic prion transmissible by different feedstuffs such as milk, meat, offals or through faeces or urine?

In this presentation, we will focus on the pros and cons of interspecies transmission of prion diseases, and the immunological properties of prion leading to a specific diagnosis test.

A specific protein present at the surface of brain cells and in nerve cells and the fibers from the nerve cells of unknown function has been described as prion or $\mathrm{PrPC}$ (prion protein). Their molecular weights vary from 30 to $35 \mathrm{kDa}$ and they have been found in various animals (especially bovine, sheep, goat, mouse and hamster) as well as in humans.

A cellular form of $\mathrm{PrP}^{\mathrm{C}}$ exists in many nonneuronal tissues of sheep and bovine such as the spleen, lymph node, lung, heart, kidney, skeletal muscle, uterus, adrenal gland, parotid gland, intestine, proventriculus, abomasum and mammary gland. However, the tissue distribution of $\mathrm{PrP}^{\mathrm{C}}$ is inconsis- tant with the tissues which possess infectivity in scrapie (Horiuchi et al, 1995). A similar protein, with the same amino acid sequence, with a molecular weight of $27-30$ $\mathrm{kDa} \mathrm{PrP}^{\mathrm{SC}}$, is present in plaque lesions, characteristic of different neurologic troubles such as scrapie in sheep, bovine spongiform encephalopathy (BSE) and CJD and Gerstmann-Straüssler-Scheinker (GSS) syndrome in humans. Prusiner (1991) recorded several observations favouring the hypothesis that normal $\operatorname{PrP}^{\mathrm{C}} 30-35 \mathrm{kDa}$ existed as a monomer in normal brain tissue or nerve cells and became a pathogenic $27-30 \mathrm{kDa}$ under a protease activity (Prusiner, 1992). PrPC is transformed into PrPSC (the prion protein of scrapie) with a different conformation, inducing the development of polymers ending to the amyloid rods found in sheep scrapie, BSE (Ye and Carp, 1995) and different human neuropathies (Laplanche et al, 1994) in connection with spongiform lesions (Prusiner et al, 1993).

Many scientists worldwide have focused their research on the structures and genetics of $\mathrm{PrP}^{\mathrm{C}}$ and $\mathrm{PrPSC}$, as well as on the epidemiology and clinical aspects of these prion diseases. Mice and hamsters were shown to be sensitive to prions from different species and were used as models to understand the transmission and development of these diseases. In this paper we will focus on the transmission and diagnosis of prion diseases in sheep and bovine.

\section{PROS AND CONS ON INTERSPECIES TRANSMISSION OF PRION DISEASES}

The diagnosis of the disease is difficult mostly because it is based on clinical signs or histological lesions which occur late in the course of the disease (lkegami et al, 1991; Race et al, 1992). Thus, with our present knowledge it is not possible to make an early diagnosis of the disease, neither in humans nor in animals. A study of the transmissibility of prions from species to 
species is also made difficult by the long incubation of the disease, which may develop several months or even years after the primary infection. Moreover, different strains of prions have been recognized with different biological properties: in sheep, for example, scrapie strains have been identified by passage from sheep to sheep or goats.

An isolate, $\mathrm{CH} 1641$, from a Cheviot sheep exhibited different properties from those known for other strains. A sip gene, which controls the incubation periods of experimental scrapie in Cheviot sheep, possesses two alleles: $s A$ which shortens and $p A$ which prolongs the incubation period of most strains of scrapie after the first experimental injection. In contrast, the $\mathrm{CH} 1641$ isolate differs from other isolates in that the alleles of sip act in the opposite way, with incubation being shorter in the $p A$ homozygotes (Dickinson et al, 1965; Foster and Dickinson, 1988). Many different experiments led to the same conclusion that scrapie agents exhibited strain diversity by injection in mice or infection of mice cells (Rubenstein et al, 1992). PrPC genotypes and natural scrapie in closed flocks of Cheviot and Suffolk sheep showed the importance of valine at codon 136 and arginine at codon 171 in Suffolk sheep (Hunter, 1996).

\section{EXPERIMENTAL TRANSMISSION}

Experimental transmission is currently used from humans or mammals to mice or hamsters. Transmission from sheep to sheep has been known for a long time (Cuille and Chelle, 1936; Gordon 1966) but it was only a few years ago that this transmission was understood with genetic implications (Goldmann et al, 1990; Hunter, 1992). Depending upon the scrapie source and route of inoculation, the incubation period varied from 197 to 595 days in positive lines and from 313 to 917 days in resistant lines of sheep, when injected intracerebral- ly with infectious brain, while resistant sheeps injected subcutaneously survived (Hunter, 1992). A linkage was found between sheep major histocompatibility complex and scrapie susceptibility/resistance locus in Ile-de-France sheep progenies (Millot et al, 1988). Similarly infected sheep brain given as food or injected intracerebrally in goats induced the disease in the goats (Pattison et al, 1974).

By inoculating cattle intramuscularly, subcutaneously, intracerebrally and orally with the scrapie agent from Suffolk sheep or goat, neurologic signs appeared between 27 and 48 months later in three animals (Clark et al, 1995). Brain lesions were characterized by moderate astrocytosis with sparse rod cells, some neuronal degeneration and scant spongiform change (Clark et al, 1995). Conversely, the transmission of BSE to sheep and goats was obtained by injecting into the right parietal cortex with $0.5 \mathrm{~mL}$ of $1 / 10$ (N/V) homogenate of brains from BSE-infected cattle. BSE was also confirmed in both 'positive' and 'negative' lines of Cheviot sheep after oral dosing with brain homogenate derived from cattle with BSE (Foster et al, 1993).

In mice or hamsters, however, it was shown that the presence of $\mathrm{PrPC}^{\mathrm{C}}$ is necessary for the development of the disease after inoculation of infected brain from sheep or bovine (Brandner et al, 1996): in transgenic mice without the mouse $\mathrm{PrP}^{\mathrm{C}}$ gene, no transmission is possible, while in chimeric mice without the mouse gene but with the human gene, CJD can be transmissible (Telling et al, 1994).

In vitro tissue culture of mice neuroblastoma made it possible to develop prions from different species (Priola et al, 1994a, b), but it is difficult to draw conclusions from the results obtained in tissue culture to in vivo systems.

From these experiments, it can be concluded that, in general, prion diseases can be transmitted to animals of the same species by oral, cerebral and peritoneal routes, but, 
for the most part, high doses were used $\left(10^{5}-10^{8}\right.$ infecting doses). Interspecies transmissions have been studied essentially in mice or hamsters but also in some monkeys: it was shown that transgenic animals having incorporated the gene from the animal species which will be the donor of PrPSC became susceptible. Similarly, transmission of CJD from humans was possible in transgenic mice expressing chimeric human-mouse prion protein.

One main problem is to understand which tissue or excreta are pathogens and can be transmitted to other animals or humans. All researchers agree that the brain and some nervous fibers are infectious; however, there is little agreement on the infectiousness of the blood, liver, ovary, adrenals, oesophagus, kidney or on the time when infectiousness appears in these tissues during the disease. Most of the work has been applied on experimental infected mice or hamsters, which often have been injected with enormous amounts of brain tissue extracts.

\section{NATURAL TRANSMISSION}

Scrapie was first recognized in sheep and goats more than 300 years ago and chemical study and histology described it 40 years ago (Brugere-Picoux, 1996). The disease developed in small areas of different countries, particularly in the southeast of France. As a few animals in the flock exhibited the disease, research focused mainly on the clinical signs, epidemiology and histology and little progress was made on the infectious agent.

In sheep, high levels of infectiousness have been found in peripheral organs only in the spleen and low levels in the pancreas (Ye and Carp, 1995). In animals with scrapie, the same prion-resistant protein (PrPres) was found in $87 \%$ of the spleen and lymph nodes (Race et al, 1992). In naturally infected goats, infectivity was found in the alimentary tracts, including the proxi- mal and distal colon; 'scrapie virus' was detected at low titre in lymphatic tissues and in the intestine in clinically normal 10- to 14month-old lambs. The central nervous system was not found to be involved until about 25 months of age - an oral route of transmission was postulated (Pattison et al, 1974; Hadlow et al, 1982). Using histological and immunohistochemical procedures in $98 \%$ of scrapie-affected sheep, $\mathrm{PrPSC}^{\mathrm{S}}$ was detected in the spleen, retropharyngeal lymph node, mesenteric lymph node and palatine tonsil (Van Keulen et al, 1996).

As only a few animals in a flock are infected and express clinical signs, studies on natural transmission are more difficult and most of them conclude on oral transmission of ovine scrapie or bovine spongiform encephalopathy. There are several reasons why strictly oral transmission is favoured:

i) in humans, kuru, with clinical signs resembling those of scrapie was transmitted from human to human in cannibalistic people from New Guinea (Gajdusek and Zigas, 1957). The disease disappeared after cannibalism was suppressed (Gajdusek, 1990);

ii) infectivity was recognized in the ileum of cattle challenged orally with BSE (Wells et al, 1994);

iii) the appearance of BSE followed ingestion by cattle of meat and brain extracts from scrapie-infected sheep (or eventually a new bovine agent) and BSE largely decreased in England from 1993 to 1996 after food products from scrapie or BSE-infected animals were banned;

iv) the appearance of prion disease in cats has arisen from dietary BSE exposure (Wyatt et al, 1991).

Most prion disease transmission between species is limited by a species barrier determined by prion strain types. In reported cases of transmission from cattle to sheep, from sheep to cattle or from cattle to cats, neither meat nor milk has been believed to be involved, but rather mainly brain and spinal cord. Numerous tissues and secretions 
from cattle naturally infected with BSE given orally to mice failed to transmit the disease, with the exception of the brain and spinal cord. In particular $10 \mathrm{~L}$ of milk collected from each of six pregnant cows showing clinical signs of BSE were used to feed or inject in mice and no neurological disease occurred in any of the 275 mice which survived for more than 300 days (Taylor et al, 1995).

\section{IMMUNOLOGICAL PROPERTIES AND DIAGNOSIS OF SCRAPIE AND BSE}

As stated by Barry and Prusiner (1987), "For nearly 30 years, investigators have been frustrated in their attempts to demonstrate or induce scrapie-specific antibodies in natural and experimental hosts". Almost ten years later, this statement still holds. Antibodies are generally obtained by injecting animals either with purified or semi-purified $\mathrm{PrP}^{\mathrm{C}}$ or PrPsC polymers or rod-shaped particles or amyloid extracted from sheep (Barry and Prusiner, 1987), bovine (Foster et al, 1993) or mice (Ye and Carp, 1995). For several reasons peptides have been used as immunogens in order to avoid the production of non specific antibodies, binding as well $\mathrm{PrPC}^{\mathrm{C}}$ or PrPSC from different species.

The main difficulty is that in infected animals, whatever the species studied, there is no immune response: the fact that PrPSC is a modified form of a cellular host component present in the brain and neurons (Oesch et al, 1985) led to experiments showing, in infected mice, a state of tolerance different from the state of tolerance described as a state of T cell "ignorance" (Berg, 1994). Thus, it was concluded that "mice are tolerant to both self $\mathrm{PrP}^{\mathrm{C}}$ and modified $\mathrm{PrPSC}^{\mathrm{SC}}$, therefore to infectious scrapie particles, due to the clonal deletion of PrP reactive $T$ cells during their development in the thymus" (Berg, 1994). It should be remembered, however, that by using ovalbumin or bovine serum albumin as antigens, low doses of orally administered antigens favour active suppression, while higher doses favour clonal allergy with the participation of the gut-associated lymphoid tissue (Galt) and the bronchial-associated lymphoid tissue (Balt) (Weiner et al, 1994). There is a balance between T cells inducing an immune response and $T$ cells leading to a tolerant state, which depends upon the properties of the antigen: for instance, while milk whey protein induced both oral tolerance and a systemic humoral response, heat denatured whey protein induced only oral tolerance (Enomoto et al, 1993). Similarly, induction of anergy or active suppression following oral tolerance was observed, depending upon the dosage of hen egg white lysozyme in the mouse, or guinea pig myelin protein in the rat (Friedman and Weiner, 1994). These different host reactions were concomitant with modifications of secretion of different cytokines such as transforming growth factor $\beta$ (TGF- $\beta$ ) IL-2, IL- 4 and interferon $\gamma$. Thus, the state of tolerance characterized by an apparent suppression of immune response in sheep scrapie or in BSE might be regulated by different cytokines stimulated by PrPSC, which would be different in the tolerant state induced by $\mathrm{PrPC}$. As cytokines would regulate proteases in autoimmune diseases (Opdenakker and van Damme, 1994), the expression and the role of proteinase $\mathrm{K}$ might be dependent upon the structure of PrPsC, compared to the structure of $\mathrm{PrPC}$, but also of the different cytokines stimulated by these different structures. The measure of different cytokines in the blood, the spinal cord fluid or the saliva might be of help for an early diagnosis of prion diseases in sheep and cows.

Another immunological aspect of prion in sheep and bovine is the specificity of polyclonal and monoclonal antibodies which have been obtained by injecting $\mathrm{PrP}^{\mathrm{C}}$ or $\mathrm{PrP}^{\mathrm{SC}}$ from different animal species in rabbits, hamsters or mice. For instance, immunization of the rabbit with purified $\mathrm{PrP}^{\mathrm{SC}} 27$ - 
30 led to antisera exhibiting greater relative reactivity against native versus denatured scrapie proteins (Barry and Prusiner, 1987). Some cross-reactivity was observed between $\mathrm{PrP}^{\mathrm{C}} 30-35$ and $\mathrm{PrP}^{\mathrm{SC}_{2}} 27-30$, whatever antigen was used for any kind of immunological test, and Prusiner et al (1993) could write "at present there is no pretest to detect BSE in animals". A similar conclusion could be made for scrapie in sheep and prion diseases in hamsters and mice. However, a recent preclinical test for prion using antibodies detected $\mathrm{PrPSC}$ in tonsillar biopsies before the expected onset of clinical disease (Schreuder et al, 1996). In humans after digestion of $\mathrm{PrPC}^{\mathrm{C}}$ in brain homogenates by proteinase $\mathrm{K}$, Western blotting was shown to be specific for the detection of prion disease (Tateishi and Kitamoto, 1993). More recently, some monoclonal antibodies were able to distinguish ovine PrP from bovine PrP. However, no detectable increase in cell surface expression of PrP was observed when scrapie injected to healthy animals was compared (Animal Health Compton Laboratory, 1995).

We suggest that this failure is mainly due to the immunization: antibodies obtained from a species by injection of a protein extracted from another species are induced by foreign epitopes (antigenic part of the molecule) which are common to $\mathrm{PrPC}^{\mathrm{C}}$ and to $\mathrm{PrPSC}^{\mathrm{SC}}$. In order to obtain monoclonal antibodies able to bind specifically $\mathrm{PrP}^{\mathrm{SC}}$ of scrapie, for instance, such antibodies should be prepared with fusion of ovine cells and B cells from immunized sheep. The same should be true for BSE. Other approaches could be used. Thus, postmortem histology and early diagnostic methods such as immunohistochemistry applied to tonsils can be used to detect spongiform encephalopathy.

\section{CONCLUSION}

$\mathrm{PrP}^{\mathrm{C}}$ is a normal protein found in the central nervous system and neurons whose function is unknown. During scrapie infection, this modified protein (27-30 kDa instead of $30-35 \mathrm{kDa}$ ) is found in the brain in the form of fibers or amyloid but can also be found in lymphoid tissues, especially in the spleen, and also in placental material. It is absent in milk, colostrum and faeces (Hourrigan et al, 1979).

The pathogenic protein causes scrapie in sheep and BSE in cows and, recently, a few cases were recorded in cats and monkeys. While known for centuries in sheep and goats, there was no natural transmission to other species until 1986, when the first cases of BSE were recorded in Great Britain in bovine. A few exceptions have been described in mule deer (Williams and Young, 1980). The origin of this interspecies transmission is administred by the oral absorption of prions present in ovine brain and meat given as feed to bovine. As for kuru in humans, when such a practice was banned, BSE began to disappear. Experimental transmission is possible by the oral route in individuals of the same species or related species (sheep, goat, bovine) and also by intracerebral and intraperitoneal routes from species to species (hamstermouse, sheep-bovine) when high doses are used, with an incubation period of months or even years.

No transmission from meat or milk to humans has been demonstrated and no proof has been found of the presence of prions in nervous fibers in meat. Prions diseases are characterized immunologically by the absence of detectable immune responses and these antigens were recognized as poor immunogens. However, polyclonal and monoclonal antibodies were obtained, which were unable to distinguish the normal $\mathrm{PrP}^{\mathrm{C}}$ from the pathogenic PrPSC. Methods of diagnosis to detect prions diseases based on clinical observation and early diagnosis is impossible. No evidence of transmission of the disease from animals to humans exists; in fact, an association with CJD is purely speculative with our present knowledge. 


\section{REFERENCES}

Animal Health Compton Laboratory (1995) Annual Report

Barry RA, Prusiner SB (1987) Immunology of prions. In: Prions: Novel Infections Pathogens Causing Scrapie and Greutzfeldt-Jakob Disease. (SB Prusiner, MP McKinley, eds) Academic Press, New York, USA

Berg LJ (1994) Insights into the role of the immune system in prion diseases. Proc Natl Acad Sci USA 91, 429-432

Brandner S, Isenmann S, Raeber A, Fischer M, Sailer A, Kobayashi Y, Marino S, Weissmann C, Aguzzi A (1996) Normal host prion protein necessary for scrapie-induced neurotoxicity. Nature $379,339-343$

Brugere-Picoux J (1996) Aspects cliniques des encéphalopathies spongiformes transmissibles animales. In: Médecine et maladies infectieuses. XXII Symposium National de Médecine Agricole, 25. 251-258

Clark W, Hourrigan JL, Hadlow WJ (1995) Encephalopathy in cattle experimentally infected with the scrapie agent. Am J Vet Res 56, 606-612

Cuille J, Chelle PL (1936) Pathologie animale. La maladie dite tremblante du mouton est-elle inoculable? CR Acad Sci 26, 1552-1554

Dickinson AG, Young GB, Stamp JT, Renwick CC (1965) An analysis of natural scrapie in Suffolk sheep. Heredity 20, 485-503

Enomoto A, Konishi M, Hachimura S, Kaminogawa (1993) Milk protein fed as a constituent of the diet induced both oral tolerance and a systemic humoral response, while heat-denatured whey protein induced only oral tolerance. Clin Immunol Immunopathol 66, 136-142

Foster JD, Dickinson AG (1988) The unusual properties of $\mathrm{CH} 1641$, a sheep-passaged isolate of scrapie. Vet Rec 123, 5-8

Foster JD. Hope J, Fraser H (1993) Transmission of bovine spongiform encephalopathy to sheep and goats. Vet Rec 133, 339-341

Friedman A, Weiner HL (1994) Induction of anergy or active suppression following oral tolerance is determined by antigen dosage. Proc Natl Acad Sci USA $91,6688-6692$

Gajdusek DC (1990) Subacute spongiform encephalopathies: transmissible cerebral amyloidoses caused by unconventional viruses. In: Virology, 2 nd edn (BN Fields, DM Knipe, RM Chanock, MS Hirsch, JL Melnick, TP Monath, eds) Raven Press, New York, USA, 2289-2324

Gajdusek DC, Zigas V (1957) Degenerative disease of the control nervous system in New Guinea. N Engl J Med 257, 974-978

Goldmann W, Hunter N, Foster JD, Salbaum JM, Beyreuther, Hope J (1990) Two alleles of a neuronal protein gene linked to scrapie in sheep. Proc Natl Acad Sci USA 87, 2476-2480

Gordon WS (1966) Variation in susceptibility of sheep to scrapie and genetic implications. In: ARS 91-53.
Report of scrapie seminar 1964, US Department of Agriculture, Washington, DC, USA, 53-67

Hadlow WJ, Kennedy RC, Race RE (1982) Natural infection of Suffolk sheep with scrapie virus. $J$ Infect Dis 146, 657-664

Horiuchi M, Yamazaki N, Ikeda T, Ishiguro N, Shinagawa $M(1995)$ A cellular form of prion protein ( $P r P^{C}$ ) exists in many non-neural tissues of sheep. J Gen Virol 76, 2583-2587

Hourrigan J, Klingsporm A, Clark WW, de Camp M (1979) Epidemiology of scrapie in the United States. In: Slow Transmissible Diseases of the Nervous System, vol 1 (SB Prusiner, WJ Hadlow, eds) Academic Press, New York, USA, 331-356

Hunter N (1992) Scrapie in sheep and goats. In: Progress in Sheep and Goat Research (AW Speedy. eds) CAB International, 131-151

Hunter N (1996) PrP genotypes and natural scrapie in closed flocks of Cheviot and Suffolk sheep in Britain. IIIrd International symposium on transmissible subacute spongiform encephalopathy prion diseases and protection against transmission risks, 18-20 March, Paris, France

Ikegami $\mathrm{Y}$, to $\mathrm{M}$, Isomura $\mathrm{H}$, Momotani $\mathrm{E}$, Sasaki $\mathrm{K}$, Muramatsu $Y$, Ishiguro, Shinagawa M (1991) Preclinical and clinical diagnosis of scrapie by detection of PrP protein in tissues of sheep. Vet Rec 128, 271275

Laplanche JL, Delasnerie-Laupêtre N, Brandel JP, Chatelain J, Beaudry P, Alpérovitch A, Launay JM (1994) Molecular genetics of prion diseases in France. Neurology 44, 2347-2351

Millot P, Chatelain J, Dautheville C, Salmon D, Cathala $F(1988)$ Sheep major histocompatibility (OLA) complex: linkage between a scrapie susceptibility/resistance locus and the OLA complex in lle-de-France sheep progenes. Immunogenetics 27, 1-11

Oesch B, Westaway D, Walchli M, Mc Kinley MP, Kent BH, Aebersold R, Barry RA, Tempst P, Teplow DB, Hood LE, Prusiner SB, Weissmann C (1985) A cellular gene encodes scrapie PrP 27-30 protein. Cell 40, $735-746$

Opdenakker G, Van Damme J (1994) Cytokine-regulated proteases in autoimmune diseases. Immunol Today 15, 103-107

Pattison JH, Hoare MN, Jebbett JN, Watson WA (1974) Further observations in the production of scrapie in sheep by oral dosing with foetal membranes from scrapie-affected sheep. Br Vet J 130, 65-67

Priola SA, Caughey B, Race RE, Chesebro B (1994a) Heterologous PrP molecules interfere with accumulation of protease-resistant PrP in scrapie-infected murine neuroblastoma cells. J Virol 94, 4873-4878

Priola SA, Caughey B, Raymond GJ, Chesebro B (1994b) Prion protein and the scrapie agent: in vitro studies in infected neuroblastoma cells. Infect Agents Dis 58, 54-58

Prusiner S (1991) Molecular biology of prion disease. Science 252, 1515-1522

Prusiner S (1992) Chemistry and biology of prions. Biochemistry $31,12277-12288$ 
Prusiner SB, Füzi M, Scott M, Serban D, Serban H, Taraboulos A, Gabriel JM, Wells GAH, Wilesmith JW, Bradley R, DeArmond JW, Kristensson K (1993) Immunologic and molecular biologic studies of prion proteins in bovine spongiform encephalopathy. $\mathrm{J} / \mathrm{n}$ fect Dis $167,602-613$

Race R, Ernst D, Jenny A, Taylor W, Sutton D, Caughey B (1992) Diagnostic implications of detection of proteinase K-resistant protein in spleen, lymph nodes, and brain of sheep. Am J Vet Res 53, 883-889

Rubenstein R, Deng H, Race RE, Ju W, Scalici CL, Papini MC, Kascsak RJ, Carp RI (1992) Demonstration of scrapie strain diversity in infected PC12 cells. $J$ Gen Virol 73, 3027-3031

Schreuder BEC, Van Keulen LSM, Vromans MEN, Langeveld JPM, Smits MA (1996) Preclinical test for prion diseases. Nature 381,563

Tateishi J, Kitamoto T (1993) Developments in diagnosis for prion diseases. Br Med Bull 49, 971-979

Taylor DM, Ferguson CE, Bostock CJ, Dawson M (1995) Absence of disease in mice receiving milk from cows with bovine spongiform encephalopathy. Vet Rec 136,592

Telling GC, Scott M, Hsiao KK, Foster D, Yang SL, Torchia M, Sidle KC, Collinge J, Dearmond SJ, Prusiner SB (1994) Transmission of Creutzfeldt-Jakob disease from humans to transgenic mice expressing chimeric human-mouse prion protein. Proc Natl Acad Sci USA 91, 9936-9940
Van Keulen LJM, Schreuder BEC, Meloen RH, MooijHarkes G, Vromans MEW, Langeveld JPM (1996) Immunohistochemical detection of prion protein in lymphoid tissues sheep with natural scrapie. J Clin Microbio/ 34, 1228-1231

Weiner HL, Friedman A, Miller A, Khoury SJ, AI-Sabbagh A, Santos L, Sayegh M, Nussenblatt RB, Trentham DE, Hafler DA (1994) Oral tolerance: immunologic mechanisms and treatment of animal and human organ-specific autoimmune diseases by oral administration of autoantigens. Annu Rev Immunol $12,809-837$

Wells GAH, Dawson M, Hawkins SAC, Green RB, Dexter I, Francis ME, Simmons MM, Austin AR, Horigan MW (1994) Infectivity in the ileum of cattle challenged orally with bovine spongiform encephalopathy. Vet Rec 135, 40-41

Williams ES, Young S (1980) Chronic wasting disease of captive mule deer: a spongiform encephalopathy. $J$ Wildlife Dis 16, 89-98

Wyatt JM, Pearson GR, Smerdon TN, Gruffydd-Jones TJ, Wells GAH, Wilesmith JW (1991) Naturally occurring scrapie-like spongiform encephalopathy in five domestic cats. Vet Rec 129, 233-236

Ye X, Carp RI (1995) The pathological changes in peripheral organs of scrapie-infected animals. Hist Histopathol 10, 995-1021 